Katarzyna Simonienko 1, 2, Martyna Jakubowska³ , Beata Konarzewska ${ }^{4}$

${ }^{1}$ Centrum Terapii Lasem w Białymstoku

${ }^{2}$ Centrum Zdrowia Psychicznego Meandra w Białymstoku

${ }^{3}$ SPP ZOZ im. S. Deresza w Choroszczy

${ }^{4} K$ linika Psychiatrii Uniwersytetu Medycznego w Białymstoku

\title{
Shinrin-yoku i terapia lasem - przegląd literatury
}

\section{Shinrin-yoku and forest therapy: review of the literature}

\begin{abstract}
Forest therapy and shinrin-yoku are concepts that have been appearing more and more often in the literature on the prevention of stress and immune disorders for over a dozen years. In the context of research, it can be said that it plays an important role not only in the prevention of somatic civilization diseases, such as hypertension or diabetes, but also protects against development and helps in the treatment of mental disorders from the group of anxiety-depressive disorders. In the "Pub Med" database, the search terms "shinrin-yoku" were entered, 23 results and "forest bathing", 90 results, of which 18 were rejected after repetitive and unrelated searches. Only original papers were analysed (30).

Forest therapy eliminates the effects of stress caused by numerous external factors generated by lifestyle in an urbanized environment and, for example, by overworking. It increases immunity, affecting, among others on the amount and activity of NK cells, it has a positive effect on metabolic parameters in ischemic heart disease and hypertension. It supports relaxation, attention and convalescence after stress. In Asian countries, it is an official branch of medicine, which is dedicated to profiled medical centers. In European countries we often meet conferences dedicated to forest therapies and specialized trainings.

Forest therapy is a well-documented therapeutic method that can be used in the prevention, support of treatment and rehabilitation of stress disorders and civilization diseases.
\end{abstract}

Psychiatry 2020; 17, 3: 145-154

Key words: complementary therapies, forest, climatotherapy, nature therapy, ecotherapy

\section{Wstęp}

Praktyka zawodowa lekarza psychiatry jest wyjątkowa pod względem holistycznego podejścia do na pacjenta. Mimo że organem, którym się zajmuje, jest mózg, biochemicznie - neuroprzekaźniki, przy zbieraniu wywiadu nie może pomijać szczegółów dotyczących nie tylko ogólnej somatyki, ale też stylu życia, środowiska, relacji rodzinnych i społecznych pacjenta. Im bardziej lekarz psychiatra traktuje pacjenta jako na całość funkcjonującą w różnych systemach, tym łatwiej z pewnej odległości,

Adres do korespondencji:

Katarzyna Simonienko

Centrum Terapii Lasem

ul. Wesoła 36 m 14, 15-306 Białystok

e-mail: k_simonienko@wp.pl zrozumieć istotę problemu i znaleźć potrzebne rozwiązania. Jednym z nurtów, który promuje takie podejście, jest ekopsychiatria - termin wprowadzony już w latach 70. XX wieku przez Amerykańskie Towarzystwo Psychiatryczne (APA, American Psychiatric Association). W ekopsychiatrii zwraca się uwagę w dużej mierze na środowisko, w jakim pacjent funkcjonuje, nie tylko społeczne, ale też naturalne, gdzie zaburzenia mogą się ściśle wiązać z problemami psychicznymi jednostki. Przebywanie w zdrowym środowisku przyrodniczym może mieć pozytywny wpływ terapeutyczny. Autorzy niniejszej pracy przeanalizują to zjawisko. Artykuł poświęcono naukowym aspektom formy rehabilitacji, profilaktyki i wspomagania leczenia farmakologicznego zwanej terapią lasem (forest therapy). 
W piśmiennictwie światowym spotyka się także japoński termin shinrin-yoku — oznaczający dosłownie kąpiel leśną. Mianem tym określa się spokojny, powolny spacer w lesie, w trakcie którego doświadcza się otoczenia za pomocą wszystkich zmysłów. W Japonii i Korei shinrin-yoku poświęcone są liczne centra medyczne i specjalne trasy leśne. Trend ten zaczyna się obserwować również w USA i Europie. Pierwszy raz termin pojawił się oficjalnie w 1982 roku, kiedy na porośniętej prastarym lasem cedrowym wyspie Yakushima zespół naukowy profesora Miyazaki postanowił sprawdzić, jak środowisko leśne wpływa na drogach biochemicznej i percepcyjnej na ludzki organizm [1]. Czterdziestominutowe spacery po lesie porównano do tej samej długości wysiłku w odpowiednio dobranych warunkach laboratoryjnych. Stosowany potem w licznych badaniach kwestionariusz stanów nastroju POMS (Profile of Mood States) pomógł ustalić, że to właśnie po leśnej kąpieli badani czuli się pełni wigoru, obniżał się u nich poziom stresu, złości i zmęczenia. Zmniejszyło się również stężenie kortyzolu w ślinie, co wykazało spadek fizjologicznego stresu. W 1998 roku opublikowano po raz pierwszy opisującą shinrin-yoku pracę zarejestrowaną przez wyszukiwarkę Pub Med. Ohtsuka i wsp. [2] zbadali wpływ terapii lasem na chorych na cukrzycę typu 2 i stwierdzili istotny spadek stężenia glukozy we krwi badanych, a efekt nie zależał od pokonanej odległości (wysiłku). Rząd japoński stworzył specjalny projekt „Fizjologiczne skutki działania leśnych komponentów środowiskowych na ludzi”, w ramach którego przeprowadzono liczne badania naukowe [3] W Polsce kąpiele leśne czy terapia lasem stają się również coraz popularniejsze i wchodzą do kanonu profilaktyki chorób cywilizacyjnych [4].

\section{Analiza piśmiennictwa}

W bazie danych „Pub Med” wpisano hasła „shinrin-yoku", uzyskując 23 wyniki (13 prac badawczych) oraz "forest bathing", uzyskując 90 wyników, z czego po odrzuceniu powtarzających się $w$ poprzednim wyszukiwaniu oraz nie związanych z tematem pozostaje 18 (1 przegląd, 17 prac badawczych). Spośród wybranych 41 prac 11 to przeglądy piśmiennictwa, a pozostałe 30 - prace badawcze, których analizą zajęto się w niniejszym artykule. Prace te zestawiono $w$ tabelach 1 i 2 .

\section{Mechanizmy działania terapii lasem Czynniki aerobiologiczne}

Jednym z mechanizmów działania terapii lasem jest tak zwany bioaerozol, w którego skład wchodzą unoszące się w powietrzu organizmy żywe oraz wytwarzane przez nie produkty, jak pyłek, strzępki grzybni czy organiczne substancje chemiczne - olejki eteryczne czy fitoncydy.

\section{Mikrobiota}

W glebie, w warstwie przyglebowej, na liściach, igłach i korze, a także w leśnym powietrzu bytują mikroorganizmy specyficzne dla danego środowiska leśnego. Im bardziej bioróżnorodny jest las, tym większe bogactwo żyjących w nim mikroorganizmów, które często wiążą się z określonym typem roślinności. Ich obecność wpływa korzystnie na organizm człowieka, który absorbuje mikrobiotę drogami oddechową i pokarmową. W naturalny sposób stymuluje to odporność, ale ma też wiele innych działań. Zgodnie z teorią „nadmiernej sterylności” brak ekspozycji na naturalnie występujące mikroorganizmy, nadmierna higiena oraz nadużywanie antybiotyków przyczyniają się do rozwoju alergii i problemów z odpornością [5]. Na szczególną uwagę zasługuje Mycobacterium vaccae -glebowa bakteria tlenowa. Ekspozycja na nią ułatwia leczenie chorób dermatologicznych, jak atopowe zapalenie skóry czy łuszczyca, jak również stanów depresyjnych i lękowych. Wpływając na system immunologiczny, pobudza ona do działania neurony serotoninergiczne, czego dowiodły wyniki badań na myszach [6].

\section{Fitoncydy}

Są to substancje wytwarzane przez rośliny w celach obronnych lub komunikacyjnych [7, 8]. Rosyjski uczony, Borys Tokin odkrył, że w styczności z zagrażającymi organizmami niektóre rośliny wydzielają substancje odstraszające, ale też o właściwościach biobójczych: przeciwbakteryjnych, przeciwgrzybiczych czy przeciwwirusowych, między innymi $\alpha$-pinen, $\beta$-pinen czy linolen. Te z kolei, wchłaniane przez ludzi, nie tracą swoich właściwości, wspomagając organizm ludzki w walce z chorobami. Stymulują układ immunologiczny, nie tylko podczas infekcji, ale także w procesie nowotworowym. Ponadto, ich wdychanie redukuje poziom fizjologicznego stresu [9] oraz korzystnie wpływa na kolejne mikrośrodowiska — na przykład profil flory jelitowej ssaków [10]. Można pokusić się o porównanie, że fitoncydy są czymś w rodzaju hormonu lub neuroprzekaźnika w złożonym organizmie naturalnego ekosystemu. Las jako skomplikowany, nieustannie, choć bez udziału świadomości większości organizmów, komunikujący się ze sobą kompleks, dąży do stabilizacji. W jego „interesie” są więc regeneracja i zdrowie jego poszczególnych komponent, w tym ssaków, a zatem również ludzi. Zdrowsze organizmy, które pośrednio korzystają z fitoncydów, wydają zdrowsze potomstwo, populacje się stabilizują, na czym zyskuje cały ekosystem. Ludzie, jako jego część, są zatem naturalnym beneficjentem procesów, które, jeśli przebiegają w sposób niezakłócony, prowadzą między innymi do wzmocnienia organizmu. 


\section{Olejki eteryczne}

Terpenowe związki organiczne są wytwarzane przez rośliny i znane ze swoich właściwości przeciwzapalnych oraz redukujących stres fizjologiczny. Mechanizmy ich działania są różne, miedzy innymi oparte na inhibicji wytwarzania prostaglandyn i aktywności cyklooksygenaz, obniżeniu aktywności kinaz białkowych MAPK, ekspresji jądrowego czynnika kappa B (NF- $\kappa$ B, nuclear factor $\kappa \mathrm{B}$ ) oraz produkcji interleukin, czynnika martwicy nowotworów alfa (TNF- $\alpha$, tumor necrosis $\alpha$ ), ochronie przed stresem oksydacyjnym czy wpływie na aktywność komórek NK [11]. Mogą działać też bezpośrednio na patogeny chorobotwórcze, zaburzając integralność ich ścian i błon komórkowych. Ich wdychanie skuteczne wspomaga leczenie chorób układu oddechowego, a zewnętrzna ekspozycja - w licznych chorobach skóry [12]. Do innych istotnych czynników terapeutycznych należy wilgotność powietrza - w lasach bardziej optymalna dla naszych dróg oddechowych, stabilniejsza i zazwyczaj o kilka procent wyższa od miejskiej. Brak przesuszania błon śluzowych chroni przed infekcjami i ułatwia swobodne oddychanie.

Jonizacja powietrza, która w lasach ma większe wartości ujemne, pozostaje nadal tematem kontrowersyjnym ze względu na brak jednoznacznych badań. Część wyników sugeruje jednak, że korzystne dla naszego zdrowia ujemne jony mogą wpływać na redukcję objawów depresyjnych [13, 14]. Mniejsza ekspozycja na czynniki stresogenne, jak wiatr, hałas, sztuczne oświetlenie, spaliny czy zanieczyszczające powietrze cząstki stałe, również odgrywają tu istotną rolę. Ważne jest też nasłonecznienie (bogatsze w widmo z zakresu światła niebieskiego i zielonego — redukujące stres fizjologiczny). Mniejsze natężenie światła słonecznego zmniejsza uczucie irytacji, lasy usytuowane wyżej, cechujące się niższym ciśnieniem atmosferycznym zmniejszają uczucie przygnębienia [15].

Większość badań przeprowadzono w Japonii lub Korei, projektowano je na podobnej zasadzie. Wybierano dwie grupy - badaną, którą eksponowano na środowisko leśne, oraz kontrolną - dobraną pod względem płci i wieku, która taką samą ilość czasu spędzała w środowisku zurbanizowanym, zwykle w centrum dużego miasta. Część badaczy dzieliła ekspozycję na bierną, gdzie sadzano badanych na krześle w danym środowisku, i czynną, gdzie uczestnicy eksperymentu mieli za zadanie spacerować w niespiesznym tempie na danej trasie. Trasy były identyczne pod względem długości i stopnia trudności, badani nie mogli w trakcie eksperymentów komunikować się ze sobą ani korzystać z urządzeń elektronicznych. Parametry życiowe, testy psychologiczne oraz badania laboratoryjne wykonywano w zależności od doświadczenia na początku, przed ekspozycją bierną, po ekspozycji biernej i przed czynną, po ekspozycji czynnej, lub, w przypadku prostszych doświadczeń, przed i po ekspozycji czynnej. Badania czasem trwały kilka dni, istotne były wyniki z początku doświadczenia pierwszego dnia i po ostatniej ekspozycji.

\section{Wpływ terapii lasem na ciśnienie i tętno oraz czynniki ryzyka choroby niedokrwiennej serca}

Badając wpływ terapii lasem na układ krążenia, naukowcy wzięli pod uwagę nie tylko ciśnienie krwi i tętno, lecz również czynniki ryzyka choroby niedokrwiennej serca, jak parametry układu renina-angiotensyna-aldosteron (RAA), stężenie osoczowej endoteliny czy mechanizmy antyoksydacyjne.

Wykonano 8 badań mierzących wpływ kąpieli leśnych na ciśnienie tętnicze oraz 7 - na tętno. Czasy ekspozycji czynnej wynosiły od 14 minut dla ekspozycji biernej i 15 minut dla ekspozycji czynnej jednorazowo do czasu tygodnia -2 razy dziennie eksponowano badanych przez półtorej godziny (tab. 1-3). W większości badań wykazano, że wartości ciśnienia tętniczego były istotnie niższe po spacerach w lesie [11, 16-18,], w jednym z badań zauważono też, że po spacerze w mieście ciśnienie rozkurczowe było istotnie wyższe [19]. Notowano istotny spadek ciśnienia krwi zarówno po ekspozycji czynnej, jak i biernej $[20,21]$. W jednym badaniu populacyjnym nie wykazano związku między częstością chodzenia po lesie a częstością występowania nadciśnienia tętniczego [22]. Po kąpielach leśnych istotnemu obniżeniu [23] ulegało też tętno [11, 17, 23, 24], zarówno po ekspozycji czynnej, jak i biernej [20].

Zbadano również wpływ shinrin-yoku na parametry choroby niedokrwiennej serca u pacjentów z niewydolnością krążenia: stężenie osoczowej endoteliny 1 (ET1), reniny, angiotensynogenu, angiotensyny II, receptora angiotensyny II typu 1 i 2 . W grupie miejskiej zaobserwowano znacząco wyższe stężenie ET-1 w stosunku do wyjściowego i grupy leśnej po ekspozycji, co sugeruje, że spacery w centrum miasta wcale nie wpływają korzystnie na krążenie w grupie ryzyka. Stężenie reniny, angiotensynogenu i angiotensyny II okazały się znacząco niższe w grupie leśnej w porównaniu z miejską, wskazując na pomocny wpływ terapii lasem $w$ tej grupie badanych [25]. W kolejnych badaniach dotyczących zdrowia osób starszych z chorobą niedokrwienną serca wykazano, że stężenia angiotensyny 1 i 2 były niższe w grupie leśnej, podobnie jak parametry układu RAA, zaobserwowano też sprawniejsze mechanizmy antyoksydacyjne. W grupie seniorów chorych na nadciśnienie tętnicze stężenia endoteliny 1, homocysteiny, reniny, angiotensynogenu, angiotensyny II oraz receptorów angiotensyny II typu 1 
i 2 również były niższe w porównaniu z grupą miejskiej i stanem wyjściowym [26, 27].

\section{Wpływ terapii lasem na układ nerwowy}

W wielu badaniach dotyczących terapii lasem oceniano pracę autonomicznego układu nerwowego- komponenty współczulnej odpowiedzialnej za reakcje walki i ucieczki oraz przywspółczulnej, aktywnej podczas relaksu i odpoczynku. Ich aktywność mierzy parametr zmienności rytmu zatokowego (HRV, heart rate variability). Jest to powtarzające się cyklicznie występowanie różnic odstępów między załamkami R w badaniu EKG, a odzwierciedla pracę układu autonomicznego serca. W sytuacji stresowej, której wykładnik stanowi zmniejszenie aktywności komponenty przywspółczulnej, i zwiększenie współczulnej, serce zaczyna bić w sposób bardziej jednostajny, więc HRV ulega zmniejszeniu. Jest to szczególnie niekorzystne u pacjentów po zawale serca, wiąże się z pracą pod presją, lękiem, przewlekłym stresem oraz zamartwianiem się [28]. Komponenty HRV to częstotliwość wysoka (HF, high frequency) — odzwierciedlająca głównie pracę układu przywspółczulnego, częstotliwość niska (LF, low frequency) — odzwierciedlająca pracę całego układu autonomicznego oraz wskaźnik LF/HF związany głównie z układem współczulnym.

W badaniach nad shinrin-yoku wykazano, że podczas kąpieli leśnych aktywność przywspółczulna odpowiedzialna za redukcję stresu i uczucie relaksu stawała się istotnie wyższa, a współczulna, związana ze stresem, istotnie niższa [23] zarówno przy czynnej, jak i biernej ekspozycji już po kwadransie [20]. W czasie spacerów leśnych rósł czynnik HRV [24] oraz HF, a LF spadał [21]. W jednym badaniu nie zaobserwowano powyższych różnic [29]. Sprawdzano też czynność bioelektryczną mózgu amplitudę fal alfa w EEG, których obecność świadczy o poziomie relaksu i dobrego nastroju, a także fal beta odpowiadających procesom zwiększonej koncentracji uwagi i orientacji na rozwiązywanie problemów [30-32]. Wykonywano badanie elektroencefalograficzne (EEG) u osób spacerujących po lesie oraz w środowisku miejskim, gdzie ruch uliczny był intensywny. Zaobserwowano wyższe średnie wartości zarówno fal alfa, jak i beta podczas przebywania w lesie, a ich wysokość zależała od czasu spaceru. Różnice między dwiema grupami cechowała istotność statystyczna [19]. Wywnioskowano, że w lesie skupienie, spostrzegawczość i szybkość podejmowania decyzji stają się sprawniejsze, bardziej zwraca się uwagę na otoczenie, przy czym nie męczy to tak, jak w warunkach biurowych czy w ruchu ulicznym. Pomimo większego zaangażowania w procesy poznawcze, pozostajemy jeszcze bardziej wypoczęci i odprężeni. Aktywność mózgu oceniano również na podstawie hemodynamiki - mierzono stężenie oksykemoglobiny (Oxy-Hb) w lewej i prawej korze przedczołowej mózgowia za pomocą funkcjonalnej spektroskopii bliskiej podczerwieni (NIRS, near-infrared spectroscopy) oraz spektroskopii czasowo-rozdzielczej (TRS, time-resolved spectroscopy). Dzięki technice NIRS emitowane promienie lasera przechodzą przez czaszkę, przez co obraz kości jest przezroczysty, a uwidaczniana jest wyłącznie krew — ta zawierająca tlen absorbuje inne częstotliwości fal świetlnych niż odtlenowana — dzięki temu można śledzić zużycie tlenu przez różne obszary mózgu i na tej podstawie oceniać jego metabolizm oraz pracę. Zaobserwowano znaczące obniżenie oksyhemoglobiny w prawej korze przedczołowej po spacerze leśnym w badaniu NIRS [29]. W technice TRS aktywność mózgowa w obszarze przedczołowym również była istotnie niższa po spacerze [33].

\section{Wpływ terapii lasem na odporność}

Układ immunologiczny jest złożonym systemem i biorą w nim udział różne rodzaje komórek, w tym pochodne komórki progenitorowej limfocytów. Znajdują się wśród nich limfocyty B, T oraz naturalni zabójcy - komórki NK (natural killers) odpowiedzialne za zjawisko naturalnej cytotoksyczności, biorące udział w immunologicznej odpowiedzi nieswoistej, na przykład przy zakażeniach wirusowych lub likwidacji komórek nowotworowych. Ich ilość i aktywność wiąże się ze sprawnością reakcji odpornościowej. Zespół profesora Li w wielu badaniach sprawdzał wpływ kąpieli leśnych na odporność, między innymi na komórki NK oraz limfocyty cytotoksyczne uwalniające białka odpowiedzi immunologicznej: granzymy, perforynę i granulizynę. Substancje te służą do niszczenia komórek uznawanych przez organizm za niebezpieczne. Zbadano grupę kobiet, u której po spacerach shinrin-yoku zaobserwowano znaczący spadek procentowy limfocytów T oraz wzrost liczby i aktywności komórek NK, a także białek antynowotworowych (granulizyna, perforyna, granzymy A i B), który utrzymywał się jeszcze tydzień po doświadczeniu [34]. W leśnym powietrzu wykryto fitoncydy drzew iglastych: $\alpha$-pinen i $\beta$-pinen. W podobnym badaniu $w$ grupie mężczyzn otrzymano analogiczne wyniki [35]. Zaobserwowano, że prawie wszyscy badani mieli zwiększoną aktywność komórek NK przynajmniej o 50\%, różnice między pierwszym a drugim dniem eksperymentu w liczbie komórek NK oraz limfocytach obwodowych krwi wydzielających badane białka antynowotworowe były istotne statystycznie [36].

\section{Wpływ terapii lasem na procesy zapalne}

Mao i wsp. [26] przebadali wpływ shinrin-yoku na parametry stanu zapalnego: stężenia mózgowego peptydu 
natriuretycznego (BNP, brain natriuretic peptide) oraz czynników zapalnych: interleukny 6 (IL-6, interleukine 6) i czynnika martwicy nowotworów alfa (TNF- $\alpha$, tumor necrosis factor alpha), a także aktywność aktywność surowiczej całkowitej dysmutazy ponadtlenkowej (T-SOD, total superoxide dismutase) i peroksydacji lipidów odzwierciedlonej w stężeniah malonodialdehydu (MDA, malondialdehyde). Zaobserwowano korzystny wpływ na organizm: znacząco niższe stężenie BNP w porównaniu z grupą miejską oraz ze stężeniem wyjściowym [26], słabszą reakcję zapalną oraz mniejszy stres oksydacyjny — obniżone stężenie MDA, znacząco niższe stężenie IL-6, TNF $\alpha$ oraz obniżone stężenie białek c-reaktywnych (CRP, C-reactive protein) i Hs-CRP (high-sensitivity CRP) [16, 27, 37, 38].

\section{Wpływ terapii lasem na stres fizjologiczny}

Podczas przewlekłego stresu nasze ciało reaguje wzmożoną aktywnością układu współczulnego oraz nadmiernym wydzielaniem niektórych substancji określanych jako markery stresu, jak na przykład kortyzol. Wyniki licznych badań dowiodły, że nawet kilkunastominutowe kąpiele leśne znacząco redukują poziom kortyzolu we krwi oraz w ślinie, nawet podczas ekspozycji biernej, kiedy badani nie ruszali się z miejsca, a jedynie odpoczywali w środowisku leśnym [16, 18, 20, 21, 23, 33]. Zbadano wpływ spaceru w lesie na młodych dorosłych: aktywność amylazy w ślinie i jej dobowy rytm wydzielania jako wyznacznik pracy układu współczulnego i stresu. Dobowe fluktuacje rytmu wydzielania amylazy w ślinie były znacznie niższe, aktywność amylazy ślinowej stanowiła doskonały wyznacznik zmian w układzie współczulnym [39]. Markery ostrego stresu, jak stężenia adrenaliny, noradrenaliny czy dopaminy w moczu również uległy istotnemu obniżeniu [18, 34, 35], czego nie obserwowano po spacerach w środowisku miejskim, a stężenie adiponektyny istotnie wzrastało [11].

Można więc wysnuć wniosek, że zarówno w stresie ostrym, jak i przewlekłym kąpiel leśna powoduje znaczący spadek „markerów stresu” [38].

\section{Wpływ terapii lasem na samopoczucie psychiczne}

Pozostaje jeszcze kwestia subiektywnego samopoczucia psychicznego oraz poziomu lęku mierzonego za pomocą testów i skal psychologicznych. W większości badań wykorzystywano Profil Stanów Nastroju (POMS, Profile of Mood States), skróconą wersję Wielokrotnej Skali Nastrojów (MMS, Multiple Mood Scale), Inwentarz Stanu i Cechy Lęku (STAl, State-Trait Anxiety Inventory) oraz skalę dyferencjału semantycznego (SD, SDM, semantic differential method). W SDM istotnie częściej po kąpieli leśnej określano swój stan jako: „komfortowy”, „zrelaksowany”, „, naturalny” [19, 29]. W STAl odnotowano istotnie niższy poziom lęku, niepokój [17, 19], wrogość, depresję, znaczący wzrost żywości. Czas pobytu nie był związany ze stopniem efektu, skala efektu terapeutycznego wiązała się z poziomem stresu — wyniki bardziej się poprawiały w stresie przewlekłym, im wyższy poziom stresu, tym lepszy był efekt [22]. W skali POMS badani istotnie częściej zaznaczali pojęcia: komfortowy, kojący, odświeżony i naturalny oraz pełen wigoru. Istotnie niższe punktacje w przedziałach napięcie-niepokój, depresja-przygnębienie, złość-nienawiść, zmęczenie, zmieszanie [11, 16-18, 23, 27, 38, 40]. Wyniki odnotowano w ekspozycjach czynnej i biernej [20]. Las był znacząco częściej odbierany jako komfortowy i spokojny [33], przywracający do zdrowia i rewitalizujący [27]. Komfort znacząco rósł po ekspozycjach czynnej i biernej na środowisko leśne, a spadał po aktywności w mieście. Te same prawidłowości dotyczyły uczucia spokoju i odświeżenia [21]. W skali SD badani znacząco bardziej czuli się „zrelaksowani” i „naturalni”[18]. Skala Regeneracji (ROS, Restorative Outcome Scale), Skala Subiektywnej Witalności (SVS, Subjective Vitality Scale), Skala oceny nastroju (PANAS, Positive and Negative Affect Schedule) wykazały w jednym z badań zwiększenie poczucia wigoru, zdrowienia i witalności, wyniki jednak nie były istotne statystycznie [41]. Co interesujące, zauważono, że lepsze wyniki osiąga się w lasach naturalnych, chociaż różnica również nie miała statystycznej istotności [42]. $\mathrm{Na}$ uwagę zasługuje też badanie przeprowadzone przez Akemi Furuyashiki [43] wśród osób z tendencjami depresyjnymi i bez takich tendencji. Okazało się, że kąpiele leśne znacząco poprawiły stan psychiczny w grupie osób tendencjami depresyjnymi, do tego stopnia, że u części z nich wyniki nie odbiegały od tych z grupy "niedepresyjnej”.

\section{Dyskusja}

Z analizy powyższych prac wynika, że praktyka kąpieli leśnych wpływa przede wszystkim na poprawę odporności organizmu oraz zmniejszenie stresu fizjologicznego i związanych z tym parametrów somatycznych, jak stężenie kortyzolu w ślinie czy wartości ciśnienia tętniczego i tętna. Jest również korzystna w profilaktyce choroby niedokrwiennej serca, wpływając na pracę układu renina-angiotensyna-aldosteron (RAA). Odnotowano łagodzący wpływ na procesy zapalne. Badania pozostawiają jednak wiele niedopowiedzeń. Nie ustalono, jak długo należy praktykować shinrin-yoku, aby efekty dla zdrowia były optymalne, w badaniach pojawiają się nawet 15-minutowe sesje, jednak nie sprawdzono, jak długo utrzymują się po nich korzystne efekty. Poprawa obserwowana przez kolejne 30 dni występowała po dwóch dniach kilkugodzinnych sesji. Mimo wielu badań, nadal nie wiadomo, jakie dokładnie mechanizmy odpowiadają za wzrost aktywności i liczebności komórek odpornościowych oraz zmniejszenie stresu. Nie ustalono, na jakiej zasadzie terapia lasem wpływa na obniżenie poziomu cukru u chorych na cukrzycę typu 2 oraz na regulację układu RAA u osób z chorobą 
Tabela1. Wyniki dla hasła "shinrin-yoku”

Table 1. Results for 'shinrin-yoku

\begin{tabular}{|c|c|c|c|c|}
\hline Autor & Rok & $\begin{array}{l}\text { Badany obszar } \\
\text { shinrin-yoku }\end{array}$ & Wyniki po ekspozycji na las & $\begin{array}{c}\text { Czas } \\
\text { ekspozycji }\end{array}$ \\
\hline $\begin{array}{l}\text { Furuyashiki } \\
\text { i wsp. [43] }\end{array}$ & 2019 & RR, POMS & $\begin{array}{c}\text { Istotna poprawa stanu psychicznego } \\
\text { u osób z tendencjami depresyjnymi, } \\
\text { spadek wartości RR }\end{array}$ & 1 dzień \\
\hline $\begin{array}{l}\text { Hassan i wsp. } \\
{[19]}\end{array}$ & 2018 & $\begin{array}{l}\text { RR, HR, EEG, stan psy- } \\
\text { chiczny (SDM, STAI) }\end{array}$ & $\begin{array}{c}\text { RR istotnie niższe, średnie wartości } \\
\text { fal alfa i beta istotnie wyższe, istot- } \\
\text { nie niższy niepokój, większy komfort } \\
\text { psychiczny. }\end{array}$ & $15 \min$ \\
\hline $\begin{array}{l}\text { Song, Ikei, } \\
\text { Miyazaki [29] }\end{array}$ & 2018 & $\begin{array}{l}\text { Stężenie Oxy-Hb } \\
\text { w korze mózgowej, } \\
\text { HVR HF, LF, SDM }\end{array}$ & $\begin{array}{l}\text { Znaczące obniżenie oxy-Hb w pra- } \\
\text { wej korze przedczołowej, brak } \\
\text { różnic w pracy układu autonomicz- } \\
\text { nego, większy komfort psychiczny }\end{array}$ & 90 sek. \\
\hline $\begin{array}{l}\text { Takayama } \\
\text { i wsp. [42] }\end{array}$ & 2017 & $\begin{array}{l}\text { Wpływ rodzaju lasu } \\
\text { na reakcje psycholo- } \\
\text { giczne }\end{array}$ & $\begin{array}{c}\text { Wyniki porównywalne, bardziej na } \\
\text { korzyść lasu naturalnego niż gospo- } \\
\text { darczego }\end{array}$ & $15 \min$ \\
\hline $\begin{array}{l}\text { Tsutsumi i wsp. } \\
{[24]}\end{array}$ & 2017 & $H R, H V R$ & Istotnie niższe HR, wyższe HVR & $90 \mathrm{~min}$ \\
\hline $\begin{array}{l}\text { Tsunetsugu } \\
\text { i wsp. [40] }\end{array}$ & 2011 & $\begin{array}{l}\text { Efekty psychologiczne } \\
\text { (ankiety, POMS) }\end{array}$ & Istotna poprawa stanu psychicznego & $15 \min$ \\
\hline $\begin{array}{l}\text { Morita i wsp. } \\
{[44]}\end{array}$ & 2011 & $\begin{array}{l}\text { Wpływ na wartości } \\
\text { RR w nadciśnieniu } \\
\text { tętniczym }\end{array}$ & $\begin{array}{l}\text { Badanie populacyjne bez istotnych } \\
\text { różnic pomiędzy częstością chodze- } \\
\text { nia po lesie a częstością występowa- } \\
\text { nia nadciśnienia }\end{array}$ & nieznany \\
\hline $\begin{array}{l}\text { Park i wsp. } \\
{[20]}\end{array}$ & 2010 & $\begin{array}{c}\text { Stężenie kortyzolu } \\
\text { w ślinie, RR, HR, HRV, } \\
\text { HF, LF/HF, stan } \\
\text { psychiczny (POMS) }\end{array}$ & $\begin{array}{l}\text { Istotnie niższe stężenie kortyzo- } \\
\text { lu, istotnie niższy HR, RR, istotnie } \\
\text { wyższa aktywność przywspółczulna } \\
\text { i niższa współczulna, istotna popra- } \\
\text { wa stanu psychicznego }\end{array}$ & $\begin{array}{l}14 \text { min } \\
\text { biernej } \\
16 \text { min } \\
\text { czynnej }\end{array}$ \\
\hline $\begin{array}{l}\text { Tsunetsugu } \\
\text { i wsp. [21] }\end{array}$ & 2007 & $\begin{array}{l}\text { RR, HR, stężenie kor- } \\
\text { tyzolu i lgA w ślinie, } \\
\text { HRV, HF, LF } \\
\text { Stan psychiczny: kwe- } \\
\text { stionariusze odczuć, } \\
\text { test S-R }\end{array}$ & $\begin{array}{c}\text { RR znacząco niższe, } \\
\text { kortyzol znacząco niższy, aktywność } \\
\text { układu przywspółczulnego wyż- } \\
\text { sza, a współczulnego niższa. Stan } \\
\text { psychiczny - poprawa. Aktywność } \\
\text { w mieście znacząco obniżała komfort. }\end{array}$ & $\begin{array}{l}15 \text { min } \\
\text { czynnej } \\
\text { i } 15 \text { min } \\
\text { biernej }\end{array}$ \\
\hline $\begin{array}{l}\text { Park i wsp. } \\
{[33]}\end{array}$ & 2007 & $\begin{array}{c}\text { Aktywność mózgowa } \\
\text { (TRS), } \\
\text { Stężenie kortyzolu } \\
\text { w ślinie, stężenie } \\
\text { hemoglobiny w korze } \\
\text { przedczołowej, } \\
\text { Skale komfortu. }\end{array}$ & $\begin{array}{l}\text { Aktywność mózgowa w obszarze } \\
\text { przedczołowym istotnie niższa; } \\
\text { kortyzol w ślinie znacząco niższy, } \\
\text { poprawa stanu psychicznego }\end{array}$ & $20 \mathrm{~min}$ \\
\hline $\begin{array}{l}\text { Morita i wsp. } \\
\text { [22] }\end{array}$ & 2007 & $\begin{array}{l}\text { Skrócona wersja } \\
\text { MMS, STAI A-State } \\
\text { Scale }\end{array}$ & Poprawa stanu psychicznego & Cały dzień \\
\hline $\begin{array}{l}\text { Yamaguchi } \\
\text { i wsp. [39] }\end{array}$ & 2006 & $\begin{array}{l}\text { Aktywność amylazy } \\
\text { w ślinie i jej dobowy } \\
\text { rytm wydzielania }\end{array}$ & $\begin{array}{l}\text { Dobowe fluktuacje rytmu wydziela- } \\
\text { nia amylazy w ślinie znacznie niższe. }\end{array}$ & $\begin{array}{l}20 \text { min, } \\
\text { spacer } \\
\text { przez } 2 \text { dni }\end{array}$ \\
\hline $\begin{array}{l}\text { Ohtsuka, } \\
\text { Yabunaka, } \\
\text { Takayama [2] }\end{array}$ & 1998 & $\begin{array}{c}\text { Poziomy cukru } \\
\text { u chorych na cukrzycę } \\
\text { typu } 2\end{array}$ & $\begin{array}{l}\text { Poziomy glukozy we krwi znacznie } \\
\text { niższe. Efekt niezależny od pokona- } \\
\text { nej odległości (wysiłku) }\end{array}$ & nieznana \\
\hline
\end{tabular}


Tabela 2. Wyniki dla hasła „forest bathing” (2015-2020)

Table 2. Results for 'forest bathing' (2015-2020)

\begin{tabular}{|c|c|c|c|c|}
\hline Autor & Rok & Badany obszar shinrin-yoku & Wyniki po ekspozycji na las & $\begin{array}{c}\text { Czas } \\
\text { ekspozycji }\end{array}$ \\
\hline $\begin{array}{l}\text { Mao } \\
\text { [37] }\end{array}$ & 2018 & $\begin{array}{l}\text { Wpływ na przewlekłą niewy- } \\
\text { dolność krążenia, poziomy BNP, } \\
\text { IL-6, TNF- } \alpha \text {, aktywność T-SOD } \\
\text { i peroksydacji lipidów, poziom } \\
\text { MDA }\end{array}$ & $\begin{array}{l}\text { Korzystny wpływ: } \\
\text { spadek poziomu BNP, osłabio- } \\
\text { na reakcja zapalna i mniejszy } \\
\text { stres oksydacyjny }\end{array}$ & $\begin{array}{l}\text { 1,5 godz. } \\
\text { przez } 4 \text { dni, } \\
\text { powtórzone } \\
\text { po czterech } \\
\text { tygodniach }\end{array}$ \\
\hline $\begin{array}{r}\text { Wu } \\
{[25]}\end{array}$ & 2017 & $\begin{array}{l}\text { Wpływ na poziom ET1 u pacjen- } \\
\text { tów z niewydolnością krążenia. } \\
\text { Poziom ET-1, reniny, angiotensy- } \\
\text { nogenu, angiotensyny II, recep- } \\
\text { tora angiotensyny II typu } 1 \text { i } 2\end{array}$ & $\begin{array}{l}\text { Stężenia reniny, angiotensyno- } \\
\text { genu i angiotensyny II } \\
\text { — znacząco niższe }\end{array}$ & Brak danych \\
\hline Yu [17] & 2017 & $\begin{array}{l}\text { Zmiany w aktywności autono- } \\
\text { micznego układu nerwowego } \\
\text { i wpływ na nastrój u seniorów. } \\
\text { HR, RR, HRV, testy POMS, STAI }\end{array}$ & $\begin{array}{c}\text { HR, RR znacząco niższe, popra- } \\
\text { wa stanu psychicznego, } \\
\text { Znacząco niższy poziom lęku } \\
\text { w STAl }\end{array}$ & 2 godz. \\
\hline $\begin{array}{l}\text { Mao } \\
{[26]}\end{array}$ & 2017 & $\begin{array}{l}\text { Seniorzy: stężenia BNP i NT-pro } \\
\text { BNP, ET-1, reniny, angiotensyno- } \\
\text { genu, angiotensyny II i recepto- } \\
\text { rów angiotensyny II typu } 1 \text { i } 2 . \\
\text { Stężenie IL-6,TNF- } \alpha \text {, aktywność } \\
\text { T-SOD, stężenie MDA }\end{array}$ & $\begin{array}{l}\text { Znacząco niższy poziom BNP } \\
\text {, angiotensyny } 1 \text { i 2, niższy } \\
\text { poziom cytokin zapalnych, } \\
\text { parametrów układu RAA, } \\
\text { sprawniejsze mechanizmy } \\
\text { antyoksydacyjne }\end{array}$ & $\begin{array}{l}\text { Cztery dni, } \\
2 \times \text { dziennie } \\
\text { po półtorej } \\
\text { godziny }\end{array}$ \\
\hline Li [11] & 2017 & $\begin{array}{l}\text { U mężczyzn w średnim wieku: } \\
\text { HR, RR. POMS Poziom adrena- } \\
\text { liny i dopaminy w moczu oraz } \\
\text { adiponektyny we krwi }\end{array}$ & $\begin{array}{c}\text { Znacząco niższe HR, niższy } \\
\text { poziom adrenaliny, znacząco } \\
\text { dopaminy (relaks), znacząco } \\
\text { wyższy adiponektyny. Poprawa } \\
\text { stanu psychicznego }\end{array}$ & $\begin{array}{l}80 \text { min rano } \\
\text { i wieczorem }\end{array}$ \\
\hline Jia [38] & 2016 & $\begin{array}{l}\text { Wpływ na POCHP u seniorów: } \\
\text { liczba komórek NK, NKT-po- } \\
\text { dobnych oraz komórek CD8+T, } \\
\text { ekspresji perforyny } \\
\text { i granzymu B. POMS }\end{array}$ & $\begin{array}{c}\text { Znaczący spadek ekspresji } \\
\text { perforyny i granzymu B, spadek } \\
\text { poziomu cytokin zapalnych } \\
\text { i hormonów stresu, } \\
\text { Spadek ekspresji granzymu B } \\
\text { na limfocytach CD8+ T oraz } \\
\text { negatywnych podskal POMS }\end{array}$ & $\begin{array}{l}\text { 1,5 godz., } \\
\text { przerwa } \\
4,5 \text { godz., } \\
\text { 1,5 godz. } \\
\text { przez } 4 \text { dni }\end{array}$ \\
\hline $\begin{array}{l}\text { Kang } \\
{[45]}\end{array}$ & 2015 & $\begin{array}{c}\text { Wpływ na przewlekły ból } \\
\text { w tylnym odcinku szyi: shinrin- } \\
\text {-yoku v. shinrin-yoku z wysiłkiem } \\
\text { fizycznym }\end{array}$ & $\begin{array}{c}\text { Liczba punktów spustowych } \\
\text { znacząco mniejsza w grupie } \\
\text { ćwiczącej, poza tym bez istot- } \\
\text { nych różnic }\end{array}$ & $\begin{array}{c}\text { Po } 2 \text { godziny } \\
\text { przez } 5 \text { dni }\end{array}$ \\
\hline $\begin{array}{l}\text { Ochiai } \\
{[18]}\end{array}$ & 2015 & $\begin{array}{l}\text { Wpływ fizyczny i psychiczny } \\
\text { na mężczyzn w średnim wieku } \\
\text { o podwyższonym RR, } \\
\text { Pomiar RR, stężenia adrenaliny } \\
\text { w moczu i kortyzolu we krwi. } \\
\text { POMS, skala TMD, dyferencjał } \\
\text { semantyczny (SD) }\end{array}$ & $\begin{array}{l}\text { RR, stężenie adrenaliny w mo- } \\
\text { czu i kortyzolu we krwi zna- } \\
\text { cząco niższy. Poprawa stanu } \\
\text { psychicznego }\end{array}$ & $\begin{array}{l}4 \text { godz. } \\
45 \mathrm{~min}\end{array}$ \\
\hline
\end{tabular}


Tabela 3. Wyniki dla hasła „forest bathing” (2007-2014)

Table 3. Results for 'forest bathing' (2007-2014)

\begin{tabular}{|c|c|c|c|c|}
\hline Autor & Rok & $\begin{array}{l}\text { Badany obszar } \\
\text { shinrin-yoku }\end{array}$ & $\begin{array}{l}\text { Wyniki po ekspozycji } \\
\text { na las }\end{array}$ & $\begin{array}{l}\text { Czas } \\
\text { ekspozycji }\end{array}$ \\
\hline $\begin{array}{l}\text { Takayama } \\
\text { [41] }\end{array}$ & 2014 & $\begin{array}{l}\text { Wpływ na stan psychiczny: } \\
\text { POMS, Skala Regeneracji } \\
\text { ROS, SVS, PANAS }\end{array}$ & Brak różnic statystycznych. & $\begin{array}{l}2 \text { dni: } 15 \mathrm{~min} \\
\text { spacer, } 15 \mathrm{~min} \\
\text { obserwacja }\end{array}$ \\
\hline Mao [16] & 2012 & $\begin{array}{l}\text { Wpływ na nadciśnienie u se- } \\
\text { niorów. RR, stężenia endote- } \\
\text { liny 1, homocysteiny, reniny, } \\
\text { angiotensynogenu, angioten- } \\
\text { syny II, receptora angiotensyny } \\
\text { II typu } 1 \text { i 2, cytokiny zapalne: } \\
\text { IL-6, TNF } \alpha \text {. POMS }\end{array}$ & $\begin{array}{l}\text { Znacząca redukcja RR, bioin- } \\
\text { dykatory niższe w porównaniu } \\
\text { do grupy miejskiej i do stanu } \\
\text { wyjściowego. Lepszy stan psy- } \\
\text { chiczny }\end{array}$ & $\begin{array}{l}7 \text { dni i nocy: } \\
\text { 1,5 godz., } \\
\text { przerwa } \\
6,5 \text { godz., } \\
1,5 \text { godziny }\end{array}$ \\
\hline Mao [27] & 2012 & $\begin{array}{l}\text { Stężenie cytokin zapalnych, } \\
\text { wskaźniki stresu oksydacyj- } \\
\text { nego, dystrybucja podzbio- } \\
\text { rów leukocytów, osoczowa, } \\
\text { poziom endoteliny 1, } \\
\text { kortyzolu. POMS }\end{array}$ & $\begin{array}{l}\text { Zmniejszone wskaźniki stresu } \\
\text { oksydacyjnego i zapalne, zna- } \\
\text { cząco niższe stężenie kortyzolu } \\
\text { we krwi, znacząco niższe } \\
\text { stężenie ET-1 we krwi. Podwyż- } \\
\text { szone stężenie limfocytów B, T, } \\
\text { Th i NK, obniżony Ts, poprawa } \\
\text { stanu psychicznego }\end{array}$ & $\begin{array}{l}2 \text { dni: } 2 \text { godz., } \\
\text { przerwa } \\
\text { przez } \\
3,5 \text { godz., } \\
2 \text { godz. }\end{array}$ \\
\hline Lee [23] & 2011 & $\begin{array}{l}\text { Wpływ psychologiczny } \\
\text { i fizjologiczny na młodych } \\
\text { Japończyków } \\
\text { HR, HRV (praca PNS i SNS), } \\
\text { kortyzol w ślinie, POMS }\end{array}$ & $\begin{array}{l}\text { Znacząco większa aktywność } \\
\text { przywspółczulną i niższą współ- } \\
\text { czulna. Znacząco niższe stężenie } \\
\text { kortyzolu w ślinie i HR. Znacząca } \\
\text { poprawa stanu psychicznego }\end{array}$ & $3 \mathrm{dni}$ \\
\hline Li [34] & 2008 & $\begin{array}{l}\text { Wpływ na aktywność komó- } \\
\text { rek NK u kobiet. } \\
\text { We krwi: aktywność i liczba } \\
\text { komórek NK, liczba komórek } \\
\text { T, oraz limfocytów wydziela- } \\
\text { jących granulizynę, perfory- } \\
\text { nę, granzymy A/B, stężenie } \\
\text { adrenaliny i noradrenaliny } \\
\text { w moczu }\end{array}$ & $\begin{array}{l}\text { Znaczący wzrost aktywności } \\
\text { i liczby komórek NK oraz komó- } \\
\text { rek wydzielających perforynę, } \\
\text { granulizynę i granzymy A/B, } \\
\text { znaczący spadek procentowy } \\
\text { komórek T, stężenia adrenaliny } \\
\text { i noradrenaliny w moczu. } \\
\text { Wzrost aktywności komórek NK } \\
\text { - ponad } 7 \text { dni }\end{array}$ & $\begin{array}{l}3 \text { dni i } 2 \text { noce } \\
\text { w lesie, dzień } \\
1 . \therefore \text { spacer } \\
2 \text { godz., } \\
\text { dzień } 2 \text {. } \\
2 \times 2 \text { godz., } \\
\text { dzień } 3 \text {. } \\
\text { - pomiary }\end{array}$ \\
\hline Li [35] & 2008 & $\begin{array}{l}\text { U mężczyzn: } \\
\text { We krwi: aktywność i liczba } \\
\text { komórek NK, liczba komórek } \\
\text { T, oraz limfocytów wydziela- } \\
\text { jących granulizynę, perfory- } \\
\text { nę, granzymy A/B, stężenie } \\
\text { adrenaliny i noradrenaliny } \\
\text { w moczu }\end{array}$ & $\begin{array}{l}\text { Znaczący wzrost aktywności } \\
\text { i liczby komórek NK oraz komó- } \\
\text { rek wydzielających perforynę, } \\
\text { granulizynę i granzymy A/B, } \\
\text { znaczący spadek procentowy } \\
\text { komórek T, stężenia adrenaliny } \\
\text { i noradrenaliny w moczu. } \\
\text { Wzrost aktywności komórek NK } \\
\text { trwała ponad } 7 \text { dni }\end{array}$ & $\begin{array}{l}3 \text { dni i } 2 \text { noce } \\
\text { w lesie, } \\
\text { dzień } 1 .: \text { spacer } \\
2 \text { godz., } \\
\text { dzień } 2 \text {. } \\
2 \times 2 \text { godz., } \\
\text { dzień } 3 \text {. } \\
\text { — pomiary }\end{array}$ \\
\hline Li [36] & 2007 & $\begin{array}{l}\text { Aktywność i liczba komórek } \\
\text { NK, liczba limfocytów krwi } \\
\text { obwodowej wydzielających } \\
\text { perforynę, granzymy i gra- } \\
\text { nulizynę }\end{array}$ & $\begin{array}{l}\text { Zwiększona aktywność komórek } \\
\text { NK co najmniej o 50\%, znaczące } \\
\text { różnice między dniem } 1 \text { a } 2 \text {. Zna- } \\
\text { cząco większa liczba komórek } \\
\text { NK, oraz wydzielających perfory- } \\
\text { ny, granulizyny i granzymów A/B }\end{array}$ & $\begin{array}{l}3 \text { dni i } 2 \text { noce } \\
\text { w lesie, } \\
\text { dzień } 1 .: \\
\text { spacer } 2 \text { godz., } \\
\text { dzień } 2 \text {. } \\
2 \times 2 \text { godz. }\end{array}$ \\
\hline
\end{tabular}


niedokrwienną serca. Brakuje danych, czy większą rolę odgrywa stymulacja zmysłowa, w tym trakt węchowy, czy też krwiopochodna, związana z inhalacją wydzielanych przez drzewa lotnych substancji czynnych. Potrzeba dalszych badań, aby dowiedzieć się więcej na temat wpływu terapii lasem na organizm.

\section{Wnioski}

Uważne spędzanie czasu w lesie ma korzystny wpływ na zdrowie psychiczne i fizyczne, redukując uczucie lęku, niepokoju, złości, wspomagając witalność, redukując stres fizjologiczny i wspomagając regenerację w takich chorobach, jak nadciśnienie tętnicze, cukrzyca czy niewydolność krążenia. Podnosi odporność, wspierając organizm w walce $z$ infekcjami i nowotworami. Uprawiane regularnie, w ciszy, utrzymuje korzystny wpływ na organizm. Korzyści wynikające z kąpieli leśnych są wielowymiarowe, dotycząc nie tylko psychiki, ale też somatyki i ogólnego funkcjonowania organizmu.

\section{Streszczenie}

Terapia lasem ishinrin-yoku to pojęcia, któreod kilkunastu lat coraz częściejpojawiają sięw literaturze dotyczącej profilaktykistresu i zaburzeń odporności. W kontekście badań można stwierdzić, że terapia lasem odgrywa istotną rolę nie tylko w zapobieganiu somatycznym chorobom cywilizacyjnym, jak nadciśnienie tętnicze czy cukrzyca, ale także chroni przed rozwinięciem oraz pomaga w leczeniu chorób psychicznych z grupy zaburzeń lękowo-depresyjnych.

W bazie danych "Pub Med" wpisano hasła "shinrin-yoku”, uzyskując 23 wyniki, oraz "forest bathing", uzyskując 90 wyników, z czego po odrzuceniu powtarzających się w poprzednim wyszukiwaniu oraz niezwiązanych z tematem pozostało 18. Przeanalizowano tylko prace badawcze (30).

Terapia lasem niweluje skutki stresu spowodowanego licznymi czynnikami zewnętrznymi, generowanymi przez styl życia w środowisku zurbanizowanym, a także na przykład z przepracowania. Podnosi odporność, wpływając między innymi na liczbę i aktywność komórek natural killers (NK), wpływa korzystnie na parametry metaboliczne w chorobie niedokrwiennej serca i nadciśnieniu tętniczym, wspomaga relaks, koncentrację uwagi oraz rekonwalescencję po stresie. W krajach azjatyckich stanowi oficjalną gałąź medycyny, której poświęcone są profilowane centra medyczne. W krajach europejskich coraz częściej organizowane są konferencje poświęcone terapii lasem oraz specjalistyczne szkolenia. Terapia lasem stanowi dobrze udokumentowaną metodę terapeutyczną i może mieć zastosowanie w profilaktyce, wspomaganiu leczenia i rehabilitacji zaburzeń stresowych i chorób cywilizacyjnych.

Psychiatry 2020; 17, 3: 145-154

Słowa kluczowe: terapie komplementarne, las, klimatoterapia, ekoterapia, terapia naturą

\section{Piśmiennictwo:}

1. Miyazaki Y, Motohashi Y. Forest environment and physical response. In: Agishi Y, Ohtsuka Y, . Recent progress in medical balneology and climatology. Hokkaido University. 1995: 67-77.

2. Ohtsuka Y, Yabunaka N, Takayama S. Shinrin-yoku (forest-air bathing and walking) effectively decreases blood glucose levels in diabetic patients. Int J Biometeorol. 1998; 41(3): 125-127, doi: 10.1007/ s004840050064, indexed in Pubmed: 9531856.

3. Nielsen A, Nilsson K. Urban forestry for human health and wellbeing. Urban Forestry \& Urban Greening. 2007; 6(4): 195-197, doi: 10.1016/j.ufug.2007.09.001.

4. Zawadka-Pietrzak J. Forest Therapy jako forma turystyki zdrowotnej. Ekonomia i Środowisko 2015; t. 4: 199-209.

5. Wold AE. The hygiene hypothesis revised: is the rising frequency of allergy due to changes in the intestinal flora? Allergy. 1998; 53(46 Suppl): 20-25, doi: 10.1111/j.1398-9995.1998.tb04953.x indexed in Pubmed: 9825991.

6. Lowry CA, Hollis JH, de Vries A, et al. Identification of an immune-responsive mesolimbocortical serotonergic system: potential role in regulation of emotional behavior. Neuroscience. 2007; 146(2): 756-772, doi: 10.1016/j.neuroscience.2007.01.067, indexed in Pubmed: 17367941

7. Tokin BP, Kamiyama KA. Mysterious phytoncide in plants (in Japanese). Tokyo, Kodansha. 1980.
8. Craig JM, Logan AC, Prescott SL. Natural environments, nature relatedness and the ecological theater: connecting satellites and sequencing to shinrin-yoku. J Physiol Anthropol. 2016; 35: 1, doi: 10.1186/s40101-016-0083-9, indexed in Pubmed: 26763049.

9. Kawakami K, Kawamoto M, Nomura M, et al. Effects of phytoncides on blood pressure under restraint stress in SHRSP. Clin Exp Pharmacol Physiol. 2004; 31 Suppl 2: S27-S28, doi: 10.1111/j.1440-1681.2004.04102.x, indexed in Pubmed: 15649280.

10. Zhang S, Jung JH, Kim HS, et al. Influences of phytoncide supplementation on growth performance, nutrient digestibility, blood profiles, diarrhea scores and fecal microflora shedding in weaning pigs. Asian-Australas J Anim Sci. 2012; 25(9): 1309-1315, doi: 10.5713/ajas.2012.12170, indexed in Pubmed: 25049695

11. Li Q, Kobayashi M, Kumeda S, et al. Effects of forest bathing on cardiovascular and metabolic parameters in middle-aged males. Evid Based Complement Alternat Med. 2016; 2016: 2587381, doi: 10.1155/2016/2587381, indexed in Pubmed: 27493670

12. Król S, Skalicka-Woźniak K, Kandefer-Szerszeń M, et al. The biological and pharmacological activity of essential oils in the treatment and prevention of infectious diseases. Postępy Higieny i Medycyny Doświadczalnej. 2013; 67: 1000-1007, doi: 10.5604/17322693.1067687.

13. Terman M, Terman JS, Ross DC. A controlled trial of timed bright light and negative air ionization for treatment of winter depres- 
sion. Arch Gen Psychiatry. 1998: 55(10): 875-882, doi: 10.1001/ archpsyc.55.10.875, indexed in Pubmed: 9783557.

14. Goel N, Terman M, Terman JSu, et al. Controlled trial of bright light and negative air ions for chronic depression. Psychol Med. 2005; 35(7): 945-955, doi: 10.1017/s0033291705005027, indexed in Pubmed: 16045061.

15. Gesler WM. Therapeutic landscapes: theory and a case study of Epidauros, Greece. Environment and Planning D: Society and Space. 1993: 11(2): 171-189, doi: 10.1068/d110171.

16. Mao GX, Cao YB, Lan XG, et al. Therapeutic effect of forest bathing on human hypertension in the elderly. J Cardiol. 2012; 60(6): 495-502, doi: 10.1016/j.jjcc.2012.08.003, indexed in Pubmed: 22948092.

17. $Y u$ CP, Lin CM, Tsai MJ, et al. Effects of short forest bathing program on autonomic nervous system activity and mood states in middle-aged and elderly individuals. Int J Environ Res Public Health. 2017; 14(8), doi: 10.3390/ijerph14080897, indexed in Pubmed: 28792445

18. Ochiai $\mathrm{H}$, Ikei $\mathrm{H}$, Song $\mathrm{C}$, et al. Physiological and psychological effects of forest therapy on middle-aged males with high-normal blood pressure. Int J Environ Res Public Health. 2015; 12(3): 2532-2542 doi: 10.3390/ijerph120302532, indexed in Pubmed: 25809507

19. Hassan A, Tao J, Li G, et al. Effects of walking in bamboo forest and city environments on brainwave activity in young adults. Evid Based Complement Alternat Med. 2018; 2018: 9653857, doi: 10.1155/2018/9653857, indexed in Pubmed: 29785198.

20. Park BJ, Tsunetsugu Y, Kasetani T, et al. The physiological effects of Shinrin-yoku (taking in the forest atmosphere or forest bathing): evidence from field experiments in 24 forests across Japan. Environ Health Prev Med. 2010; 15(1): 18-26, doi: 10.1007/s12199-0090086-9, indexed in Pubmed: 19568835.

21. Tsunetsugu Y, Park BJ, Ishii $H$, et al. Physiological effects of Shinrin-yoku (taking in the atmosphere of the forest) in an old-growth broadleaf forest in Yamagata Prefecture, Japan. J Physiol Anthropol. 2007; 26(2): 135-142, doi: 10.2114/jpa2.26.135, indexed in Pubmed: 17435356

22. Morita E, Fukuda S, Nagano J, et al. Psychological effects of forest environments on healthy adults: Shinrin-yoku (forest-air bathing, walking) as a possible method of stress reduction. Public Health 2007; 121(1): 54-63, doi: 10.1016/j.puhe.2006.05.024, indexed in Pubmed: 17055544

23. Lee J, Park BJ, Tsunetsugu Y, et al. Effect of forest bathing on physiological and psychological responses in young Japanese male subjects. Public Health. 2011; 125(2): 93-100, doi: 10.1016/j. puhe.2010.09.005, indexed in Pubmed: 21288543

24. Tsutsumi M, Nogaki H, Shimizu Y, et al. Individual reactions to viewing preferred video representations of the natural environment: A comparison of mental and physical reactions. Jpn J Nurs Sci. 2017; 14(1): 3-12, doi: 10.1111/jins.12131, indexed in Pubmed: 27160351.

25. Wu Q, Cao Y, Mao G, et al. Effects of forest bathing on plasma endothelin-1 in elderly patients with chronic heart failure: Implications for adjunctive therapy. Geriatr Gerontol Int. 2017; 17(12): 2627-2629, doi: 10.1111/ggi.13114, indexed in Pubmed: 29265753.

26. Mao G, Cao Y, Wang B, et al. The salutary influence of forest bathing on elderly patients with chronic heart failure. Int J Environ Res Public Health. 2017; 14(4), doi: 10.3390/ijerph14040368, indexed in Pubmed: 28362327.

27. Mao GX, Lan XG, Cao YB, et al. Effects of short-term forest bathing on human health in a broad-leaved evergreen forest in Zhejiang Province. China Biomed Environ Sci. 2012; 25(3): 317-324.

28. Brosschot JF, Van Dijk E, Thayer JF. Daily worry is related to low heart rate variability during waking and the subsequent nocturnal sleep period. Int J Psychophysiol. 2007; 63(1): 39-47, doi: 10.1016/j. ijpsycho.2006.07.016, indexed in Pubmed: 17020787

29. Song C, Ikei H, Miyazaki Y. Physiological Effects of Visual Stimulation with Forest Imagery. Int J Environ Res Public Health. 2018; 15(2) doi: 10.3390/ijerph15020213, indexed in Pubmed: 29373558

30. Lukas SE, Mendelson JH, Benedikt R. Electroencephalographic correlates of marihuana-induced euphoria. Drug Alcohol Depend.
1995: 37(2): 131-140, doi: 10.1016/0376-8716(94)01067-u, indexed in Pubmed: 7758402

31. Kostyunina MB, Kulikov MA. Frequency characteristics of EEG spectra in the emotions. Neurosci Behav Physiol. 1996; 26(4): 340-343, doi: 10.1007/BF02359037, indexed in Pubmed: 8912339

32. Lee BG, Lee BL, Chung WY. Mobile healthcare for automatic driving sleep-onset detection using wavelet-based EEG and respiration signals. Sensors (Basel). 2014; 14(10): 17915-17936, doi: 10.3390/ s141017915, indexed in Pubmed: 25264954.

33. Park BJ, Tsunetsugu Y, Kasetani $T$, et al. Physiological effects of Shinrin-yoku (taking in the atmosphere of the forest)--using salivary cortisol and cerebral activity as indicators. J Physiol Anthropol. 2007; 26(2): 123-128, doi: 10.2114/jpa2.26.123, indexed in Pubmed: 17435354

34. Li Q, Morimoto K, Kobayashi M, et al. A forest bathing trip increases human natural killer activity and expression of anti-cancer proteins in female subjects. J Biol Regul Homeost Agents. 2008; 22(1): 45-55, indexed in Pubmed: 18394317.

35. Li Q, Morimoto K, Kobayashi M, et al. Visiting a forest, but not a city, increases human natural killer activity and expression of anti-cancer proteins. Int J Immunopathol Pharmacol. 2008; 21(1): 117-127, doi: 10.1177/039463200802100113, indexed in Pubmed: 18336737

36. Li Q, Morimoto K, Nakadai A, et al. Forest bathing enhances human natural killer activity and expression of anti-cancer proteins. Int J Immunopathol Pharmacol. 2007; 20(2 Suppl 2): 3-8, doi: 10.1177/03946320070200S202, indexed in Pubmed: 17903349.

37. Mao GX, Cao YB, Yang Y, et al. Additive Benefits of Twice Forest Bathing Trips in Elderly Patients with Chronic Heart Failure. Biomed Environ Sci. 2018; 31(2): 159-162, doi: 10.3967/bes2018.020, indexed in Pubmed: 29606196

38. Jia BB, Yang ZX, Mao GX, et al. Health Effect of Forest Bathing Trip on Elderly Patients with Chronic Obstructive Pulmonary Disease. Biomed Environ Sci. 2016; 29(3): 212-218, doi: 10.3967/bes2016.026, indexed in Pubmed: 27109132

39. Yamaguchi M, Deguchi M, Miyazaki Y. The effects of exercise in forest and urban environments on sympathetic nervous activity of normal young adults. J Int Med Res. 2006; 34(2): 152-159, doi: 10.1177/147323000603400204, indexed in Pubmed: 16749410.

40. Tsunetsugu Y, Park BJ, Lee J, et al. [Psychological relaxation effect of forest therapy: results of field experiments in 19 forests in Japan involving 228 participants]. Nihon Eiseigaku Zasshi. 2011; 66(4): 670-676, doi: 10.1265/jjh.66.670, indexed in Pubmed: 21996766

41. Takayama N, Korpela K, Lee J, et al. Emotional, restorative and vitalizing effects of forest and urban environments at four sites in Japan. Int J Environ Res Public Health. 2014; 11(7): 7207-7230, doi: 10.3390/ijerph110707207, indexed in Pubmed: 25029496.

42. Takayama N, Fujiwara A, Saito H, et al. Management Effectiveness of a Secondary Coniferous Forest for Landscape Appreciation and Psychological Restoration. Int J Environ Res Public Health. 2017; 14(7), doi: 10.3390/ijerph14070800, indexed in Pubmed: 28718831.

43. Furuyashiki A, Tabuchi K, Norikoshi K, et al. A comparative study of the physiological and psychological effects of forest bathing (Shinrin-yoku) on working age people with and without depressive tendencies. Environ Health Prev Med. 2019; 24(1): 46, doi: 10.1186/s12199-019-0800-1, indexed in Pubmed: 31228960

44. Morita E, Kadomatsu Y, Tsukamoto M, et al. No association between the frequency of forest walking and blood pressure levels or the prevalence of hypertension in a cross-sectional study of a Japanese population. Environ Health Prev Med. 2011; 16(5): 299-306, doi: 10.1007/s12199-010-0197-3, indexed in Pubmed: 21431814

45. Kang B, Kim T, Kim MiJ, et al. Relief of Chronic Posterior Neck Pain Depending on the Type of Forest Therapy: Comparison of the Therapeutic Effect of Forest Bathing Alone Versus Forest Bathing With Exercise. Ann Rehabil Med. 2015; 39(6): 957-963, doi: 10.5535/ arm.2015.39.6.957, indexed in Pubmed: 26798610. 